\title{
Changes in Mechanical Properties of Holding Magnet Type LS50 in Liquid Metal Transfer Ladle Due to Repeated Use
}

\author{
Sumiyanto $^{1}$, Harwan Ahyadi², Rudi Sapura ${ }^{3}$, Djoko Suprijatmono ${ }^{4}$ \\ \{sumiyanto@istn.ac.id\} \\ Mechanical Engineering Study Program, National Institute of Science and Technology, South Jakarta
}

\begin{abstract}
Inside a ladle there is one component of the material that often gets damaged, namely the Holding Magnet Type LS50, which has corrosion (damage) on the surface due to temperatures that reaches $1500{ }^{\circ} \mathrm{C}$ with a time limit of 150 minutes. Test shows the material contained in the Holding Magnet Type LS50 are steel, copper (CuZn), and magnet. The Steel of Holding Magnet Type LS50 has a chemical composition with the main ingredient of iron (Fe) around $97.961 \%$ and other elements such as carbon, silicon, manganese, chromium and other alloy elements. As for the microstructure, CuZn has a microstructure in the form of an $\alpha$ (alpha) phase and a $\beta$ (betha) phase. The average of Holding Magnet hardness test results shows only CuZn experienced a very drastic decrease in the hardness value due to continuous heat exposure while the temperature for $\mathrm{CuZn}$ melting point is only $1084^{\circ} \mathrm{C}$.
\end{abstract}

Keywords: Chemical Composition, Metallography, Hardness.

DOI: $10.7176 / \mathrm{CMR} / 12-7-08$

Publication date:October 31st 2020

\section{INTRODUCTION}

As we already know that with the development of this era and its human needs, the industrial world has a very important role. In the mechanical engineering field, steel processing industry is one of them.

Metal processing industry cannot be separated from the importance of using ladle, which is an item or tool of a die casting machine that functions to take liquid metal from the holding (liquid metal reservoir) and pour the liquid metal according to the needs of production. This ladle has many sizes and types just like the casting machine. The bigger the machine size, the bigger the ladle size used. Mostly, the ladle used is the one with a capacity of 100 tons.

The pouring technique using ladle is much more profitable, because there is no need for excessive human labor to meet abundant consumer demands. However, to support this activity, treatments must be taken so that the ladle can work properly.

Inside the ladle, there is one component of the material that is often damaged, namely the Holding Magnet. Holding Magnet is a component that attached to the bottom of the ladle. The function of the Holding Magnet itself is as an adhesive for Slid Gate components or Slid Gate binders, it can be interpreted as a substitute for bolts.

There are several types of ladles, but this study will be carried out on the Holding Magnet Type LS50. Type LS50 is the serial number of the ladle used with a capacity of 100 tons.

\section{LITERATURE REVIEW}

\subsection{Ladle}

Ladle is an item or tool of die casting machine that functions to move liquid metal from the liquid aluminum reservoir continue with pouring the liquid aluminum in accordance to the needs of production. Ladle comes in many sizes and types adjusting the casting machine. The bigger the machine size, the bigger the size of ladle used.

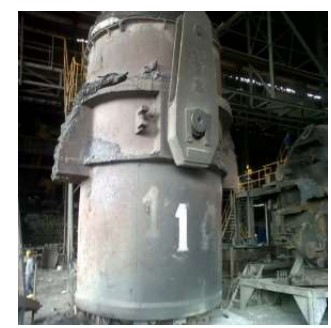

Figure 1. Ladle Type LS50. 


\subsection{Holding Magnets on Ladle}

Holding Magnets is an adhesive or a binder component. It is a substitute for bolts and clamps. Holding magnets provide an economical solution for many material handling applications involving ferrous products, through the removal of expensive clamps and fixtures. These magnets can increase productivity in the application process that includes: feeding part, automatic part transfer, welding, and holding parts in metal forming operations.

Standard holding magnets are supplied with its flat extended and ground precision mild steel poles, which can be customed by the machine to fit irregular shapes. These magnets are unaffected by vibration and are completely isolated for direct mounting to steel surfaces.

\section{Function of Magnet Holding on Ladle}

Holding Magnet is a component that is attached to the bottom of the ladle, it serves as the adhesive for the Sliding Gate component or the Sliding Gate binder

\section{Magnet Holding Parts}

The holding magnet has 3 items in it, namely:
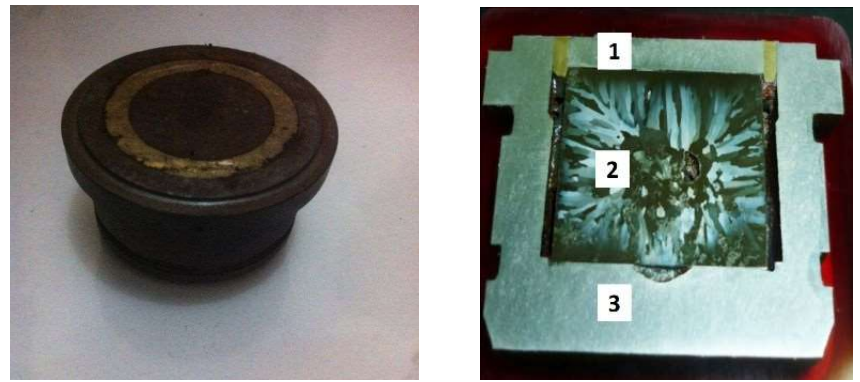

Figure 2. Holding Magnets and its parts (1. Cu; 2. Magnets; 3. Steel)

\subsection{Copper $(\mathrm{Cu})$}

Copper is an alloy made of copper $(\mathrm{Cu})$ and zinc $(\mathrm{Zn})$. This material is used in many equipment such as decorative items, screws, musical instruments, and small nails. The mixture is between copper $(\mathrm{Cu})$ with zinc $(\mathrm{Zn})$ levels varying between $10 \%-40 \%$. The higher the brass metal content, the more zinc content is.

If the zinc $(\mathrm{Zn})$ content exceeds $40 \%$, the zinc will experience a decrease in strength and when it is smelted, the zinc $(\mathrm{Zn})$ will evaporate and make the copper $(\mathrm{Cu})$ better. The copper will become harder so therefore it will be better to use machine. Zinc alloy that reaches $39 \%$ will give a mixture that is more resilient so that in cold temperatures, brass can be easily formed and it resistant to corrosion.

Copper-zinc alloys or called as brass metals can be used for heat exchangers, which is a part that strong, has a good resistant to corrosion and have a fairly high ductility. Copper-zinc alloys or brass alloys mixed with a third element can be used to improve corrosion resistance, wear resistance and machinability properties.

The manufacture of brass by casting is the only method commonly used in the small metal industry and the large metal industry. Metal casting is a smelting process or melting a metal, where the liquid metal is poured into a mold then the molten metal is allowed to cool. The casting process includes mold making, preparation, smelting, pouring the metal into the mold and further processing of the casting results.

In the process of casting brass metal within the existing small industrial environment, most of them still use the sand molding system. And in this brass metal smelting, they generally still use some used materials that are melted with a crucible furnace or with a low frequency induction furnace.

\subsection{Magnets}

The word magnet comes from the word magnesia (Greek) which means magnesian stone. Magnesia is the name of a region in Greece in the past which is now called Manisa (now in the territory of Turkey) where there are magnetic stones found since ancient times in the region. The first magnetic stones found were natural magnets (fixed magnets). Magnets that exist today are almost all artificial magnets.

\section{Types of Magnets}

Based on the type of material used, magnets can be divided into four types: 
a) Mixed Permanent Magnets

Magnetic properties of this type are hard and have a very strong attractive force. Mixed permanent magnets are divided into:

- Alcomax magnets, made from a mixture of iron with aluminum

- Alnico magnets, made from a mixture of iron and nickel

- Ticonal magnets, made from a mixture of iron and cobalt

b) Ceramic Permanent Magnets

This type of magnet is also called a magnadur, it is made of ferrite powder and is hard and has a strong attractive force.

c) Malleable Iron Magnets

This type of soft iron magnet is also called stalloy, it is made of $96 \%$ iron and $4 \%$ silicon. Its magnetic properties are not harsh and temporary.

d) Protective Magnets

This type of magnet, also known as mumetal, it is made of $74 \%$ nickel, $20 \%$ iron, $5 \%$ copper, and $1 \%$ manganese. These magnets are not hard and are temporary.

\subsection{Steel}

Steel is a vital base material for industry. All segments of life, from kitchen utensils, transportation, generators, to building frames and bridges are using steel. The exploitation of steel is ranked first among the mining and metal goods. Its products cover almost $95 \%$ of metal products used in everyday human life. day.

Steel is a metal alloy composed of iron as the main element and carbon as the reinforcing element. The carbon element plays a large role in increasing hardness. Heat treatment can change the physical properties of steel from soft like a wire to hard like a knife. The reason is that heat treatment changes the microstructure of steel and the crystal structure from $\mathrm{BCC}$ to FCC which is alloy and when cooled suddenly there is a change in crystal structure from FCC to BCC.

\section{Steel Classification Based on Chemical Composition}

Table 1. Steel classification according to its chemical composition

\begin{tabular}{|c|c|}
\hline Alloy Steel & Chemical Composition \\
\hline \multicolumn{2}{|r|}{ Carbon Steel } \\
\hline Low Carbon Steel & $0.025-0.25 \% \mathrm{C}+0.25-1.50 \% \mathrm{Mn}$ \\
\hline Medium Carbon Steel & $0.26-0.55 \% \mathrm{C}+0.25-0.80 \% \mathrm{Si}$ \\
\hline High Carbon Steel & $0.556-1.7 \%+0.04 \% \mathrm{P}(\max ), 0.05 \% \mathrm{~S}(\max )$ \\
\hline \multicolumn{2}{|r|}{ Alloy Steel } \\
\hline Low Alloy Steel & $\begin{array}{l}\text { As in low carbon steel added with alloying elements of less than } 4 \% \text { such as } \\
\qquad \mathrm{Cr}, \mathrm{Ni}, \mathrm{Mo}, \mathrm{Al} \text { and others. }\end{array}$ \\
\hline Medium Alloy Steel & As in low alloy steel with the number of alloying elements between $5-10 \%$ \\
\hline High Alloy Steel & With a total of more than $10 \%$ of alloying elements. \\
\hline \multicolumn{2}{|r|}{ Special Steel } \\
\hline \multirow{4}{*}{ Stainless steel } & Ferritic (12-30\% Cr and low carbon) \\
\hline & Martensitic $(12-17 \% \mathrm{Cr}$ and $0.1-1.0 \% \mathrm{C})$ \\
\hline & Austenitic $(17-25 \% \mathrm{Cr}$ and $8-20 \% \mathrm{Ni})$ \\
\hline & $\begin{array}{l}\text { Precipitation as in austenitic added by the combining elements: } \mathrm{Cu}, \mathrm{Ti}, \mathrm{Al} \text {, } \\
\qquad \mathrm{N} \text { and so on. }\end{array}$ \\
\hline Tool Steel & As in low alloy steels but the number of alloying elements is above $5 \%$. \\
\hline \multicolumn{2}{|r|}{ Superalloy } \\
\hline & $\begin{array}{c}\text { Nickel-based superalloy } 6 \text { to } 22 \% \mathrm{Al} \\
\text { Fe Ni base superalloy Ni-Cr / } \mathrm{Ni}>20 \% \\
\text { Cobalt Base-alloy } 20 \text { to } 30 \% \mathrm{Cr}\end{array}$ \\
\hline
\end{tabular}




\section{Carbon Steel Mechanical Properties}

The mechanical properties of metals can be controlled by heating, called as heat treatment. The mechanical properties of steel include:

a) Hardness which is the resistance of a material to plastic deformation due to local loading on the surface in the form of scratches or presses.

b) Strength is indicated by the resistance of the material to the loads imposed on it so that it changes shape or size. Part of the strength includes tensile strength, yield strength and fracture strength.

c) Ductility is the metal's ability to deform. Ductile materials usually have large cross-sectional shrinkage before fracturing occurs.

d) Deformation so the fracture of a metal takes place quickly without knowing the propagation direction

e) Toughness is the ability of a metal to maintain its shape by absorbing energy affecting it until it breaks.

\section{RESEARCH DATA}

\subsection{Chemical Composition Testing on Steel and Ring Holding Magnet Type LS50.}

Chemical composition testing was carried out at B2TKS-LUK BPPT, aiming to determine the amount of chemical element composition in the Holding Magnet Type LS50. In this test, the Holding Magnet will be checked first, then the surface is cleaned so that the testing process can run well. The testing process for the Steel of Holding Magnet Type LS50 is carried out using a spectrometer, while the Ring of Holding Magnet Type LS50 use Niton for the chemical composition test tools.

Table 3. Chemical Composition Test Results on Magnet Holding Steel.

\begin{tabular}{|c|c|}
\hline Element & Elemental Value (\% by weight) \\
\hline $\mathrm{C}$ & 0.072 \\
\hline $\mathrm{Si}$ & 0.266 \\
\hline $\mathrm{Mn}$ & 1,390 \\
\hline $\mathrm{P}$ & 0.014 \\
\hline $\mathrm{S}$ & $<0.003$ \\
\hline $\mathrm{Cr}$ & 0.220 \\
\hline $\mathrm{Mo}$ & $<0.005$ \\
\hline $\mathrm{Ni}$ & $<0.005$ \\
\hline $\mathrm{Al}$ & 0.019 \\
\hline $\mathrm{Cu}$ & 0.004 \\
\hline $\mathrm{Nb}$ & 0.021 \\
\hline $\mathrm{Ti}$ & 0.018 \\
\hline $\mathrm{V}$ & $<0.002$ \\
\hline $\mathrm{Fe}$ & 97,961 \\
\hline
\end{tabular}

Table 4. Chemical Composition Test Results on Ring Holding Magnet Type LS50 with 3 tests.

\begin{tabular}{|c|c|c|c|c|}
\hline \multirow{2}{*}{ No. } & \multirow{2}{*}{ Element } & \multicolumn{3}{|c|}{ Elemental content (\% by weight) } \\
\cline { 3 - 5 } & & Examination 1 & Examination 2 & Examination 3 \\
\hline 1 & $\mathrm{Cu}$ & 63.0 & 62.68 & 62.50 \\
\hline 2 & $\mathrm{Zn}$ & 36.26 & 36.52 & 36.70 \\
\hline 3 & $\mathrm{Sn}$ & 0.17 & 0.16 & 0.17 \\
\hline 4 & $\mathrm{~Pb}$ & 0.16 & 0.17 & 0.13 \\
\hline 5 & $\mathrm{Fe}$ & 0.16 & 0.16 & 0.20 \\
\hline 6 & $\mathrm{Ni}$ & 0.07 & 0.04 & 0.06 \\
\hline
\end{tabular}




\subsection{Microstructure Testing (Metallography)}

This test is done to get the relationship between the microstructure changes that occur in the holding magnet. In this case, the type of Holding Magnet material is observed from the aspect of its operating temperature, then the anticipated change in the metallurgical structure can occur decarburasim due to oxidation, growth of spherodized carbide metal grains, and corrosion. Figure 4 is the optical microscope for metallographic testing tool.

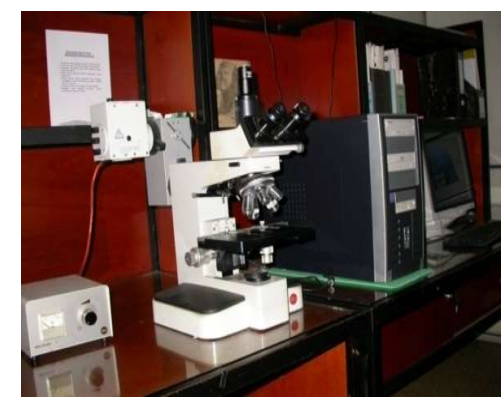

Figure 3. Optical Microscope for Metallographic Test Equipment

\subsection{Hardness Testing (Vickers)}

Hardness testing is a mechanical test that aims to determine the hardness value of the material being tested due to heat treatment. Figure 5 is the picture of the hardness test equipment (Vickers).
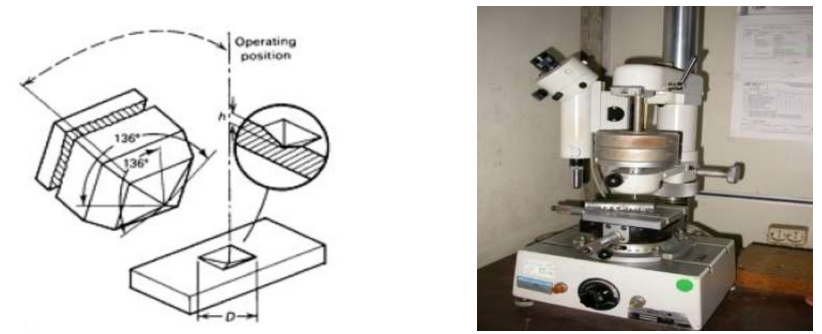

Figure 5. Hardness Testing Equipment and Diamond pyramid test indenter schematic for Vickers test and its indentation

This hardness test uses an indenter that is pressed on the test object with a certain load. This stress will cause the metal to undergo plastic deformation. The value of hardness is expressed by HV (Diamond Pyramid Number - VPN), which is the ratio between the load (P) and the compressive footprint (A). With the formula:

$$
\mathrm{HV}=\frac{2 . P \sin \frac{\alpha}{2}}{d^{2}}=\frac{2 . P \sin \frac{136}{2}}{d^{2}}=\frac{(1,8544) P}{d^{2}}
$$

$\mathrm{d}$ is the average diagonal in $\mu \mathrm{m}, \mathrm{P}$ is the load given in gf, and $\alpha$ is the surface angle $\left(136^{\circ}\right)$. Hardness can be calculated by the formula above or by converting the diagonal average in the HV (Hardness Vickers Number) conversion table book. 
Table 5. The results of hardness testing on the Holding Magnet Type LS50

\begin{tabular}{|c|c|c|c|c|}
\hline \multirow{2}{*}{ NO } & \multicolumn{4}{|c|}{ HV Hardness Value } \\
\cline { 2 - 5 } & Sample A & Sample B & Sample C & Sample D \\
\hline 1 & 180 & 61 & 139 & 152 \\
\hline 2 & 181 & 62 & 137 & 154 \\
\hline 3 & 130 & 137 & 145 & 166 \\
\hline 4 & 130 & 132 & 115 & 162 \\
\hline 5 & 133 & 116 & 118 & 152 \\
\hline 6 & 113 & 88 & 112 & 151 \\
\hline 7 & 113 & 92 & 515 & 142 \\
\hline 8 & 110 & 92 & 515 & 152 \\
\hline 9 & 515 & 515 & 515 & 152 \\
\hline 10 & 532 & 523 & - & - \\
\hline 11 & 523 & 523 & - & - \\
\hline
\end{tabular}

\section{DATA ANALYSIS}

\subsection{Steel of Holding Magnets Chemical Composition Analysis}

After testing the chemical composition of the Holding Maget Type LS50 steel, it was found that in fact its chemical composition used the main ingredient of iron (Fe) around $97.961 \%$. In addition to these elements, there are also several elements as support, these elements include carbon, silicon, manganese, chromium and other alloying elements. Inside the steel, there is an element of Manganese (Mn) that quite large, as big as $1.39 \%$ which functions to increase the fluidity, strength, and hardness of the Holding Magnet Type LS50.

\subsection{Ring of Holding Magnet Type LS50 Chemical Composition Analysis}

After the chemical composition test was carried out on the Ring of Holding Maget Type LS50 with 3 tests, it resulted in different element values using the Niton tool as shown in Table 4. Thus, from the results of the chemical composition testing above, the average value of the ring of holding magnet type LS50 chemical composition will be taken as above.

Table 4. The average value of the chemical elements in the ring Holding Magnet Type LS50.

\begin{tabular}{|c|c|}
\hline Element & Elemental Value (\% by weight) \\
\hline $\mathrm{Cu}$ & 62.72 \\
\hline $\mathrm{Zn}$ & 36.49 \\
\hline $\mathrm{Sn}$ & 0.16 \\
\hline $\mathrm{Pb}$ & 0.15 \\
\hline $\mathrm{Fe}$ & 0.17 \\
\hline $\mathrm{Ni}$ & 0.05 \\
\hline
\end{tabular}

\subsection{Micro Structure Test Results (Metallography)}

Metallographic testing has been carried out on the Holding Magnet Type LS50 to find out what kind of phases have occurred in the Holding Magnet Type LS50 for samples A, B, C and D, so it is magnified multiple times. Microstructure Test Analysis of The Undamaged Holding Magnet with 50 Minutes Usage Time (A) 
By examining the 50x and 200x magnification of the Holding Magnet Type LS50 - A in Figure 6, it shows it is in a good condition. It has a $3 \mathrm{~mm} \mathrm{CuZn} \mathrm{ring,} \mathrm{the} \mathrm{CuZn}$ microstructure is in the good condition of $\alpha$ (alpha) phase and $\beta$ (betha) phase and there are no defects. (Etching: $\mathrm{K}_{2} \mathrm{CrO}_{7}$ ).
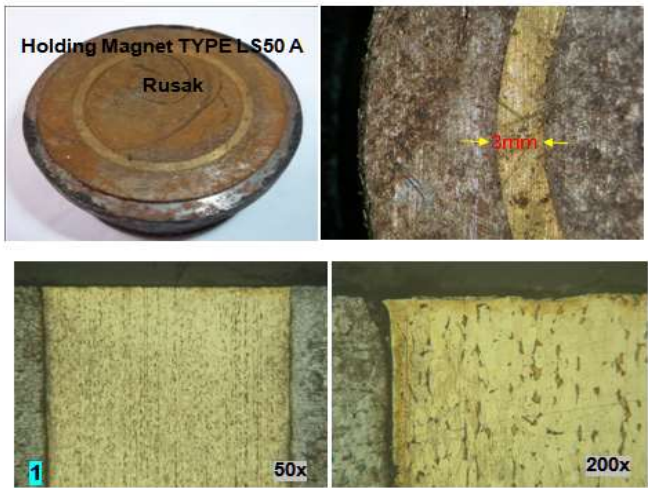

Figure 6. 50x and 200x magnification.

In Figure 7, the microstructure of location $2 \mathrm{CuZn}$ is in the form of $\alpha$ (alpha) and $\beta$ (betha) phases. It is in good condition and there are no defects.

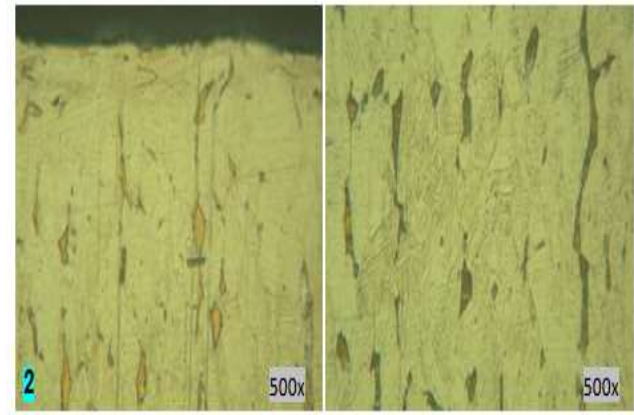

Figure 7. CuZn using 50x \& 500x Magnification

In Figure 8, The microstructure of location 3 on the Magnet Holding Type LS50 casing material is ferrite (white) and pearlite (black) in normal conditions. (Etching: nita 18\%).

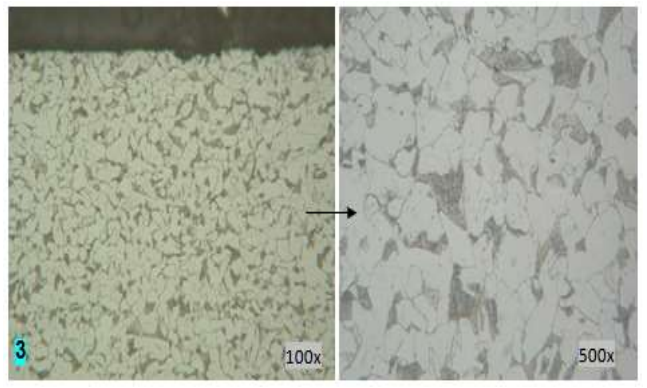

Figure 8. Magnification of $100 \mathrm{X}$ and 500X on the Holding Magnet Type LS50 steel.

As Seen in Figure 9 on the magnetic material of the holding magnet with a magnification of 12 times and 200 times, there are holes and cracks caused by heat. 


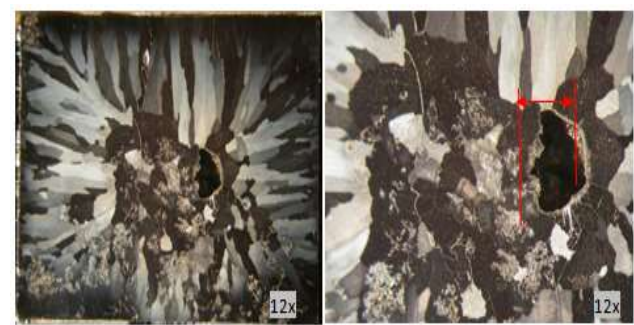

Figure 9. Magnet micro structure, there is a porous defect in the middle area and cracks through the grain boundaries (intergrannular crackings) in the form of ferritic and fine carbide grains spread evenly. (Etching: $\mathrm{K}_{2} \mathrm{CrO}_{7}$ )

\section{Microstructure Test Analysis of The Half-damaged Holding Magnet with 100 Minutes Usage Time (B)}

By looking at Figure 10, the macro photo of the Holding Magnet Type LS50 - B, it has a little damage which can be seen on the surface around the boundary between CuZn. Especially the CuZn material experiencing corrosion due to operating temperature.

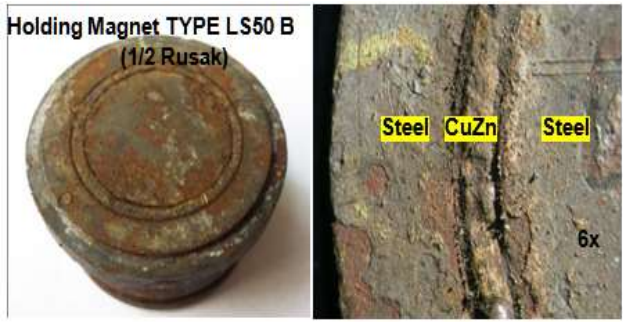

Figure 10. Macro Photo Holding Magnet LS50 with 6x and 12x Magnification

In figure 11. with a 50x and 200x magnification on $\mathrm{CuZn}$, it is very visible that there is a corrosion attack on the surface, see the arrow in the picture.
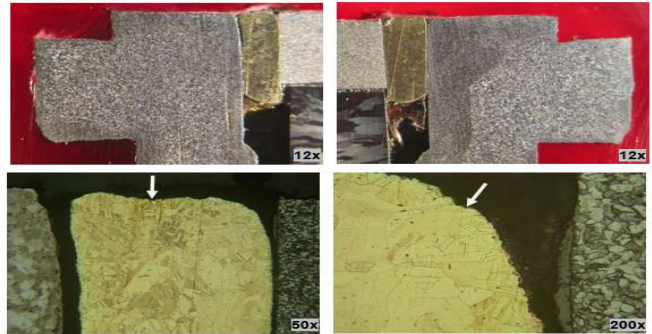

Figure 11. High temperature corrosion attack only occurs on the surface of $\mathrm{CuZn}$ material (arrow) (Etching: $\mathrm{K}_{2} \mathrm{CrO}_{7}$ )

In figure 13, picture number 2 with 500x magnification for the microstructure on the magnetic cover shows there is no change, it is still ferrite-pearlite. In picture number 3 with 50x magnification shows between the magnet and the magnetic cover there is a deposit.

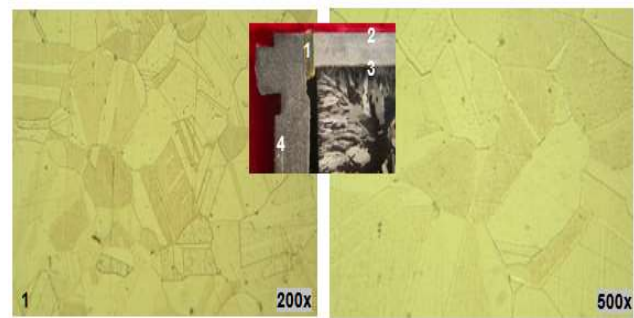

Figure 12. The micro structure of CuZn material with 200x and 500x magnification is alpha phase 


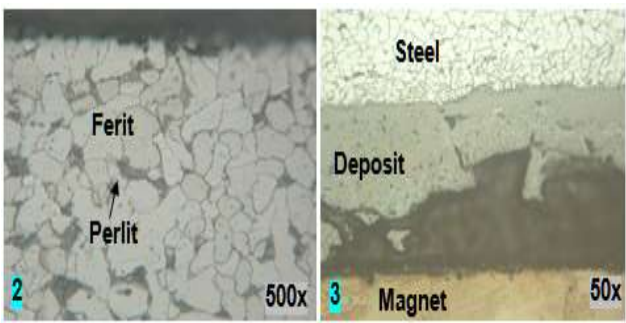

Figure 13. The microstructure of the magnetic cover is ferrite-pearlite under normal conditions.

From the micro structure in Figure 14 with magnification of 50x and 500x on the magnetic casing, it is still in form of ferrite-pearlite and there is a defect in the material, namely sulfide, where this type of sulfide corrosion defect is caused by various sulfur compounds at temperatures of $260-540{ }^{\circ} \mathrm{C}\left(500-1000{ }^{\circ} \mathrm{F}\right)$

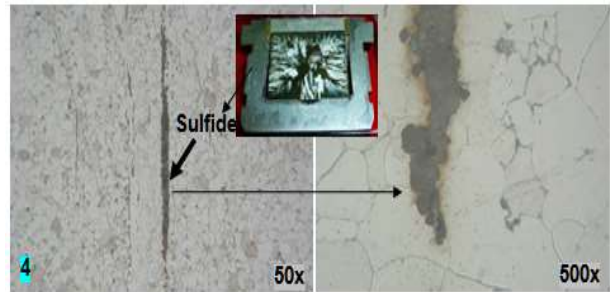

Figure 14. The micro structure of the casing is ferrite-pearlite and there is a defect in the material (Etching: $\left.\mathrm{K}_{2} \mathrm{CrO}_{7}\right)$

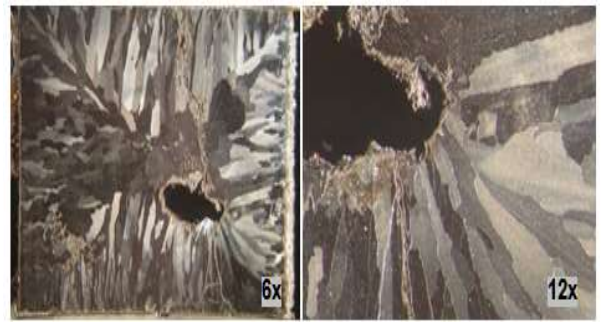

Figure 15. In the magnetic material made from the casting process, there are porous defects, the microstructure is in the form of ferritic with carbide grains spread evenly (Etching: $\mathrm{K}_{2} \mathrm{CrO}_{7}$ )

\section{Microstructure Test Analysis of The Damaged Holding Magnet with 150 Minutes Usage Time (C)}

In Figure 16, the macro photo of the Holding Magnet Type LS50 - C with damaged condition in the CuZn ring, it can be seen that the $\mathrm{CuZn}$ material surface is not visible because it experiences corrosion in its operating temperature.

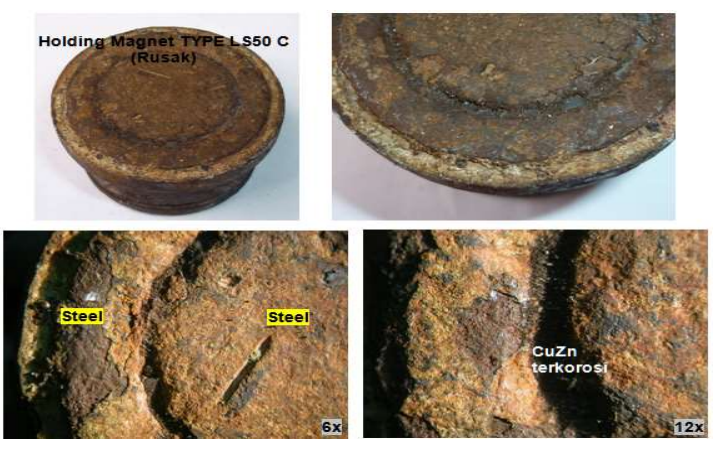

Figure 16. Macro photo of Holding Magnet LS50 C 
Examination of Figure 19, the macro photo of the Holding Magnet Type LS50 - C, the sample shows a porous defect in the central area and it undergoes transgrannular corrosion and intergrannular corrosion in the form of ferritic microstructure with chromium carbide grains spread evenly. (Etching: $\mathrm{K}_{2} \mathrm{CrO}_{7}$ )
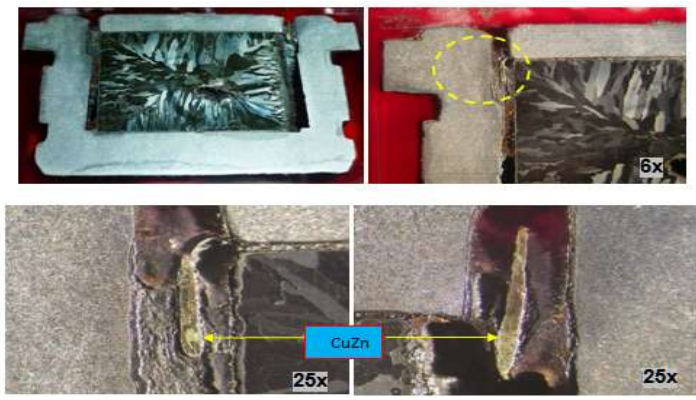

Figure 17. The enlargement of the CuZn material in the form of a ring around the Casing Holding Magnet Type LS50 experienced corrosion at operating temperature. (Etching: $\mathrm{K}_{2} \mathrm{CrO}_{7}$ )
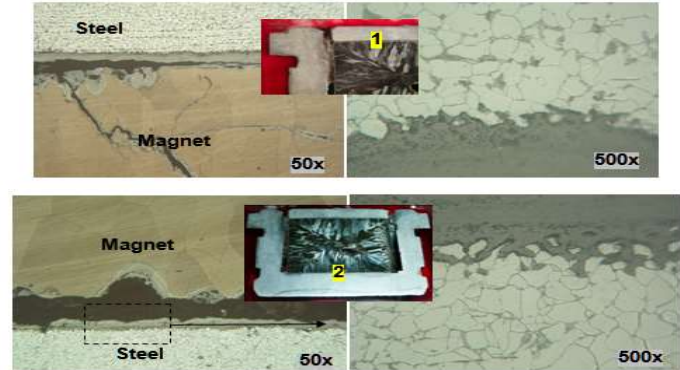

Figure 18. The effect of operating temperature on changes in the microstructure of the Holding Magnet Casing both the upper (1) and lower (2) positions does not have a major effect, which still ferrite-pearlite. (Etching: $\mathrm{K}_{2} \mathrm{CrO}_{7}$ )

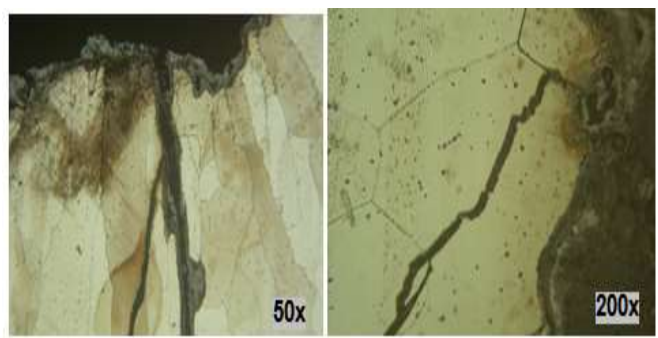

Figure 19. Macro photo of the Holding Magnet TYPE LS50 C sample with 50x and 200x magnification.

\section{Microstructure Test Analysis of The Damaged Holding Magnet with 150 Minutes Usage Time with Only the Holding Magnet Casing - D \\ Macro photo of Holding Magnet Type LS50 - D is damaged, the inspection is only on the Casing Holding} Magnet LS50, the upper surface of the steel material experiences corrosion in operating temperature.

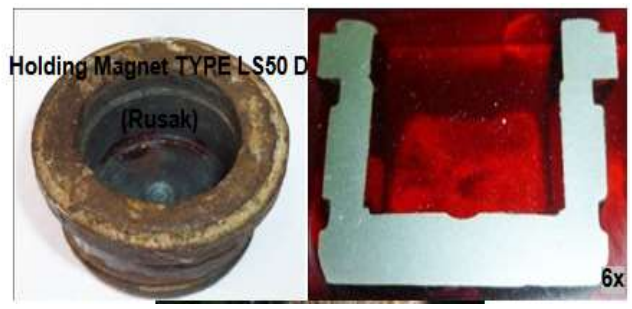

Figure 20. Macro photo of magnetic case 
In Figure 21, examining the Holding Magnet Type LS50 - D, it shows the microstructure of the casing has undergone a change from ferrite (white) and lamellar pearlite to pearlite (spherical) spheroidization, this is due to the fact that the casing is continuously exposed to high temperatures. (Etching: $12 \%$ nita)

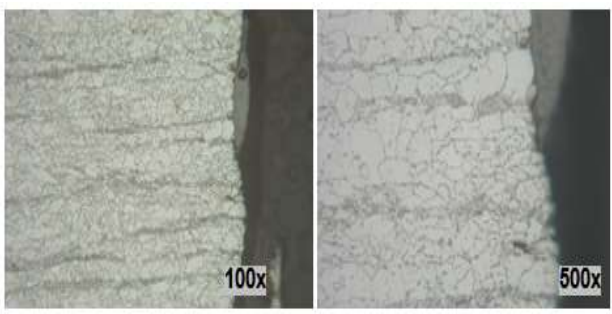

Figure 21. Magnetic casing microstructure.

\subsection{Hardness Testing Analysis (Vickers)}

After the hardness test is carried out on the Holding Magnet Type LS50, it produces a comparison value for hardness, both for steel, CuZn, and Magnet materials.

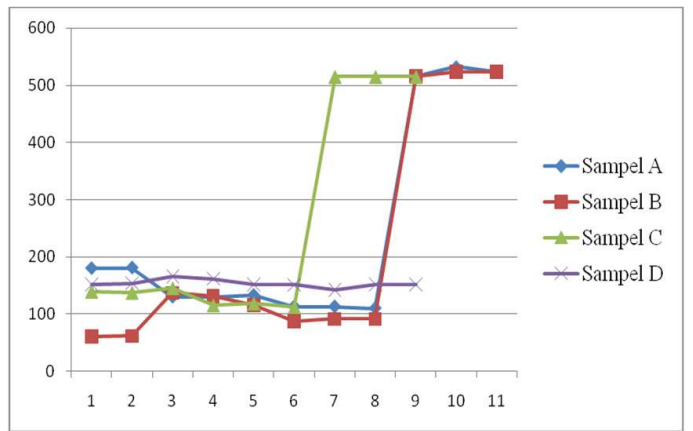

Figure 22. Graph of Holding Magnet Type LS50 hardness test results

Table 5 shows the hardness value of the steel on the Holding Magnet Type LS50. After knowing the value of the hardness test on the Steel of Holding Magnets Type LS50, the average value is taken, thus the hardness graph will be known as shown figure 23 .

Table 5.The average value of the Hardness Test on the Holding Magnet Type LS 50 steel.

\begin{tabular}{|c|c|c|c|c|}
\hline \multirow{2}{*}{ NO } & \multicolumn{4}{|c|}{ HV. VIOLENCE VALUE } \\
\cline { 2 - 5 } & Sample A & Sample B & Sample C & Sample D \\
\hline 1 & 130 & 137 & 139 & 152 \\
\hline 2 & 130 & 132 & 137 & 154 \\
\hline 3 & 133 & 116 & 145 & 166 \\
\hline 4 & 113 & 88 & 115 & 162 \\
\hline 5 & 113 & 92 & 118 & 152 \\
\hline 6 & 110 & 92 & 112 & 151 \\
\hline 7 & - & - & - & 142 \\
\hline 8 & - & - & - & 152 \\
\hline 9 & - & - & - & 152 \\
\hline Average value & 121.5 & 109.5 & 127.6 & 153 \\
\hline
\end{tabular}


Figure 23 is the graph of the hardness test average value on the Steel of Holding Magnets Type LS50. It shows that the hardness level is higher due to continuous exposure to heat, both from each type of damage.

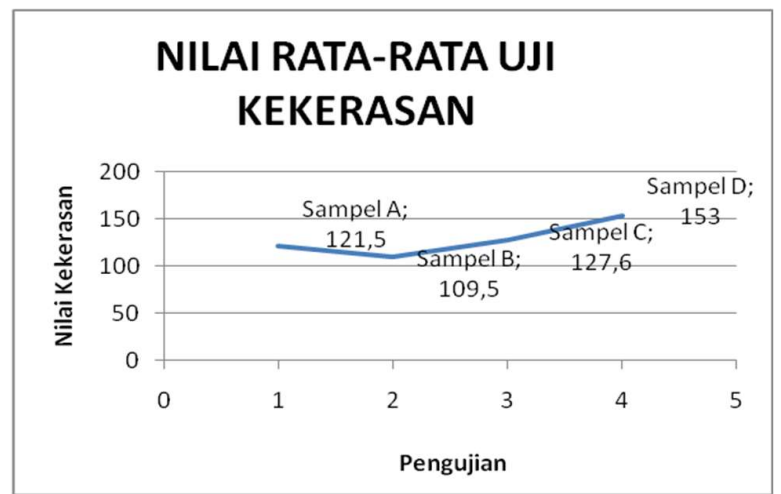

Figure 23. Graph of the hardness test average value on steel of Holding Magnets Type LS50.

From Table 6 can be seen that in samples A and B on CuZn (ring) of Holding Magnet Type LS50 has different hardness values. After testing, the average value of the hardness can be taken. The graph can be seen in Figure 24 .

Table 6. The average value of the hardness test on the CuZn (ring) Holding Magnet Type LS50

\begin{tabular}{|c|c|c|}
\hline \multirow{2}{*}{ No. } & \multicolumn{2}{|c|}{ HV. VIOLENCE VALUE } \\
\cline { 2 - 3 } & Sample A & Sample B \\
\hline 1 & 180 & 61 \\
\hline 2 & 181 & 62 \\
\hline Average & 180.5 & 61.5 \\
\hline
\end{tabular}

Judging from the Figure 24 which shows the graph of the hardness average value in CuZn samples A and B has decreased seen from the level of damage.

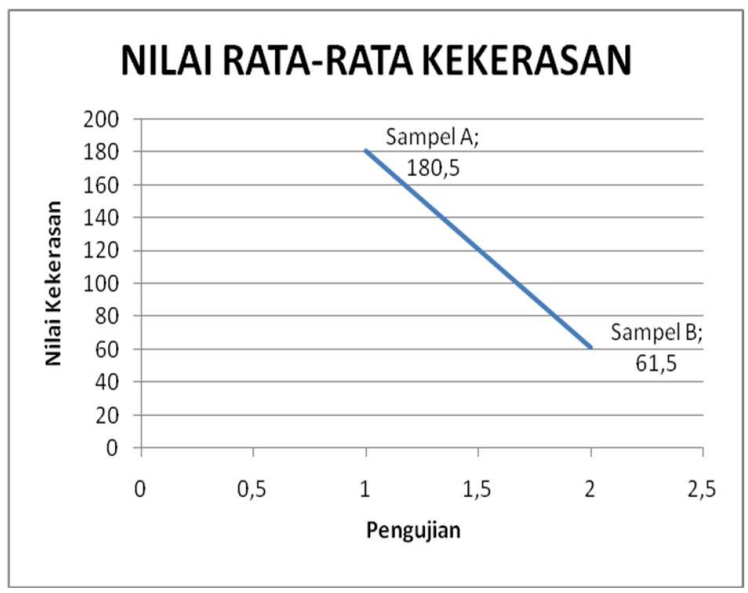

Figure 24. Graph of Average Value of hardness test on CuZn (ring) on Holding Magnet Type LS50.

Based on Table 7, it is known from several hardness tests on magnet of Holding Magnet Type LS50 has different hardness value. From the hardness value, the average hardness value in samples A, B and C can be taken. The graph for the average value of hardness on the Magnet Type LS50 can be seen in Figure 25 . 
Table 4.4. The average value of the magnetic hardness test on the holding magnet type LS50.

\begin{tabular}{|c|c|c|c|}
\hline \multirow{2}{*}{ NO. } & \multicolumn{3}{|c|}{ HV. VIOLENCE VALUE } \\
\cline { 2 - 4 } & Sample A & Sample B & Sample C \\
\hline 1 & 515 & 515 & 515 \\
\hline 2 & 532 & 523 & 515 \\
\hline 3 & 523 & 523 & 515 \\
\hline Average & 523.3 & 520 & 515 \\
\hline
\end{tabular}

Judging from the figure 25 , the graph of the hardness test average value on a magnet shows that the hardness level has decreased in terms of the level of corrosion.

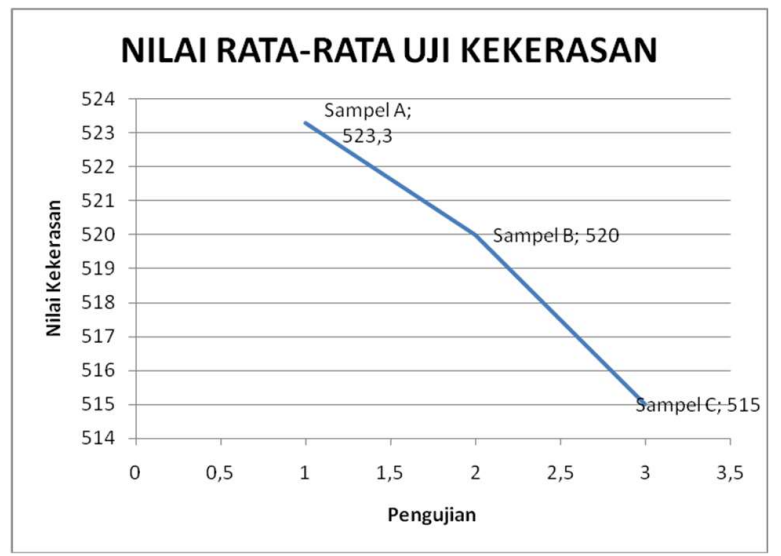

Figure 25. Graph of hardness test average value on magnet of Holding Magnet Type LS50

\section{CONCLUSION}

1. Materials contained in the Holding Magnet Type LS50 are steel, CuZn, and magnets. The Steel of Holding Magnet type LS50 has a chemical composition which uses the main ingredient of iron (Fe) around $97.961 \%$.

2. In addition to these elements, there are also several elements as support, these elements include carbon, silicon, manganese, chromium and other alloying elements.

3. Inside the steel, there is an element of Manganese (Mn) which is quite large, as much as 1.39, which functions to increase the fluidity, strength, and hardness of the Holding Magnet Type LS50. CuZn has chemical elements, including $\mathrm{Cu}$ (62.72), $\mathrm{Zn}$ (36.49), $\mathrm{Sn}(0.16), \mathrm{Pb}(0.15), \mathrm{Fe}(0.17), \mathrm{Ni}(0.05)$, and the magnets used are mixed permanent magnets.

4. From the results of microstructure testing that has been carried out on the Holding Magnet Type LS50 steel, the steel used in the Holding Magnet Type LS50 steel is low carbon steel.

5. The Holding Magnet Type LS50 steel is ferrite pearlite. And the defect contained in the Steel of Holding Magnet Type 50 is a sulfide defect.

6. For the microstructure of CuZn, the Holding Magnet Type LS50 material has a microstructure in the form of an $\alpha$ (alpha) phase and a $\beta$ (betha) phase. 
7. In the magnetic material made from the casting process, there are porous defects, the microstructure is in the form of ferritic with carbide grains spread evenly, experiencing transgrannular corrosion and corrosion through the grain boundaries (intergrannular corrosion).

8. From the average hardness test results of the Holding Magnet Type LS50 on steel (casing) still have very hard mechanical properties as well as magnets. The average value of the hardness test on the Steel of Holding Magnets Type LS50 shows that the hardness level is higher due to continuous exposure to heat, both from the type of damage.

9. The CuZn material has an average value of hardness in CuZn samples A (180.5) and B (61.5) which has a quite drastic decrease in hardness. For the magnetic material, the Holding Magnet Type LS50 has an average hardness value that decreases in terms of its corrosion rate.

\section{REFERENCES}

1. http: //cipretx.blogspot,com/

2. http://engineering.engviet.com/mesin-dan-komponen-utama/

3. http://www.softilmu.com/2015/09/Pengertian-Sifat-Teori-Bentuk-Jenis-Magnet-Adalah.html

4. http://asagenerasiku.blogspot.co.id/2012/12/magnet-sifat-bentuk-dan-cara-membuatnya.html

5. http://anangramadhana.blogspot.co.id/2013/09/material-logam-dan-non-logam-serta.html

6. Cakra Tunggal Steel Mills In Class 2015 Training Materials

7. Surdia Tata., 1989. Pengetahuan Bahan Teknik [Engineering Material Knowledge], PT. Pradian Paramita, Jakarta

8. Smallman RE and RJ Bishop, 1999. Metalurgi Fisik Moderen dan Rekayasa Material [Modern Physical Metallurgy and Materials Engineering]. Erlangga: Jakarta.

9. Surdia, Prof. Ir. Tata, MS, M Met.E and Prof. DR Shinorku Saito, 1995. Pengetahuan Bahan Teknik [Engineering Materials Knowledge], PT. Pradnya Paramita, Jakarta 